\title{
Labs cook up strategy to test transgenic food
}

\section{Alison Abbott, Munich}

The European Commission last week formally inaugurated a network of laboratories specifically charged with detecting genetically modified organisms (GMOs) in foods.

Officials hope that the labs will develop common standards for food testing, and will help to win public trust for genetically modified products by implementing new rules to govern the contents of such food.

As the network was launched, the agriculture ministers of the European Union (EU) were reaching agreement on what these regulations should say. But the rules will not be finalized until the European Parliament approves them, probably next year.

Given the public hostility to genetically modified food in Europe, most politicians support the explicit labelling of foods to inform consumers of their content.

The rules approved by the ministers would see food labelled if it comprises more than $0.9 \%$ GMOs - or products derived from GMOs - that have been approved by EU regulators. Products containing more than $0.5 \%$ GMOs that are thought to be safe, but have not yet been formally approved, would be banned from sale.

The European Network of GMO Laboratories, which employs about 450 people at more than 45 sites in the EU, will support the rules by validating and harmonizing methods for detecting specific GMOs in foods.

In the $\mathrm{EU}$, about $80 \%$ of the products on sale, or awaiting approval, that contain GMOs

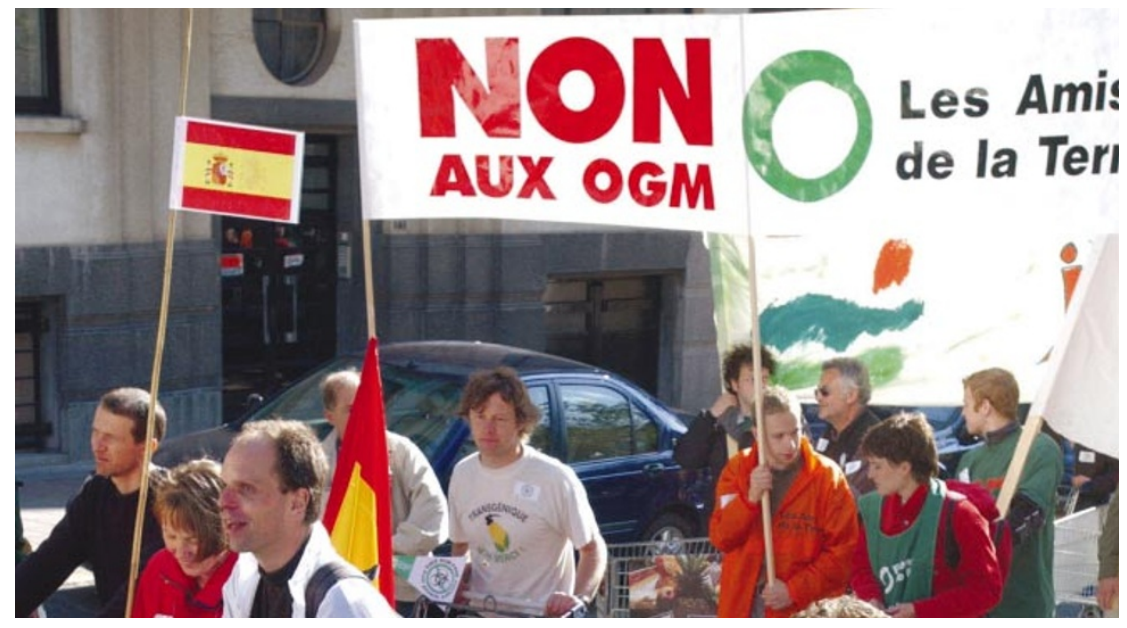

Serving suggestions: ministers hope to erode Europe's negative attitude to genetically modified foods.

have been validated on "individual initiatives by individual institutes", says Guy Van den Eede, a scientist at the Joint Research Centre's Institute for Health and Consumer Protection in Ispra, Italy, who chairs the network. "But it is important for everyone that these methods are validated in a consistent way across the EU.” The network expects to validate between five and seven GMO tests next year, he says.

The labs will test only foodstuffs that contain DNA and proteins from genetically modified plants. The final EU regulations may also call for the labelling of highly refined foods made using genetically modified materials, but which no longer contain them. The food industry has called this proposal unworkable.

The biotechnology industry has reacted positively to the laboratory initiative. "Industry has always stated that consistent methods for scientific traceability are necessary," says Simon Barber, a spokesman for EuropaBio, a group representing European biotechnology firms.

And many commission officials hope that having the labs in place will help to prepare for a lifting of the EU moratorium on new approvals for GMOs, which has been in place since 1998. So far, 18 such organisms have been approved, and 13 more are in the regulatory pipeline, pending the moratorium's end.

\section{Syngenta ready to drop plans for Indian rice venture}

\section{K. S. Jayaraman, New Delhi}

Syngenta, the Swiss-based agricultural biotechnology company, is set to withdraw from a collaborative deal that would have brought it commercial rights to a unique collection of Indian rice strains.

The ground-breaking deal would have given the company access to over 19,000 strains of local rice cultivars, painstakingly gathered by the agricultural scientist R. H. Richharia in the 1970s. In exchange, Syngenta would have provided support for collaborative research with the university that hold the seeds.

But plans to announce the agreement were postponed in October and, following harsh criticism from scientists, environmentalists and government officials, the company is now likely to abandon the plan, says Pawan Malik, president of Syngenta's seeds division in India.

Collaborations of this type are vital to the development of agricultural biotechnology in the developing world but concerns about ownership have made them very difficult to pull off.

Richharia's collection is held by the Indira Gandhi Agricultural University (IGAU) in Raipur, Chhattisgarh. The university and Syngenta were accused of excessive secrecy after the Chhattisgarh Biodiversity Security Forum, a non-profit group, revealed the existence of the negotiations. The IGAU's vice-chancellor V. K. Patil subsequently confirmed that the university had held three rounds of meetings with Syngenta since the summer to discuss an agreement whereby the two parties would jointly develop hybrid rice varieties.

Patil said that Syngenta would provide an undisclosed amount of research funding to the university in exchange for access to the collection, and would also pay seven years' worth of royalties on any new varieties it sold as a result. Patil said he was going to make the deal public at the appropriate time.

But some scientists denounced the negotiations. "Richharia's collection is a national wealth and the IGAU has no right to treat it like its private property," says E. A. Siddiq, chairman of the research advisory committee of the National Bureau of Plant Genetic Resources.

The Indian Council of Agricultural Research, the main farm-research agency, has asked the university to clarify how it negotiated with Syngenta without its knowledge.

A spokesman for Syngenta says that the negotiations took place "to explore the possibility of working together to develop new rice hybrids that meet specific farmers' needs in that part of the country".

"We have 35 research collaborations in India, but this one has not worked out well," adds Malik. He declined to identify any of the others, however. 